\title{
The Crisis of Extreme Inequality in India
}

\author{
Ishan Anand ${ }^{1} \cdot$ Anjana Thampi ${ }^{1}$ (D)
}

Accepted: 12 July 2021 / Published online: 10 August 2021

(C) Indian Society of Labour Economics 2021

\begin{abstract}
The Covid-19 pandemic and the lockdowns have exposed and exacerbated the crisis of extreme inequalities in India. Using multiple nationally representative sample surveys, we analyse various dimensions of inequality in the labour market and in the access to basic amenities. We briefly indicate our most striking findings. Substantial gaps in earnings by gender, caste and area of residence persist. On average, female earnings were $63 \%$ of male earnings, earnings of the Scheduled Castes were $55 \%$ of the earnings of the relatively advantaged social groups, and rural earnings were only half of urban earnings in 2018-2019. About 905 million people did not have access to piped water, 287 million did not have access to toilets, 127 million lived in rented accommodations, and one-fourth of the population lived in single-room dwellings in 2017-2018. The implications of the long-term neglect of the public healthcare system and the disparities in the access to education are discussed. The evidence highlights the need for a new paradigm of development-one that puts redistribution at the heart of its agenda.
\end{abstract}

Keywords Inequality $\cdot$ India $\cdot$ Earnings $\cdot$ Labour

\section{Introduction}

The dominant view of inequality in India in policy circles and among a section of influential economists has been to either deny its rise altogether or to dismiss the concerns of distribution citing increase in economic growth and fall in poverty levels. Studies have used household consumer expenditure survey data to argue that neither the levels of nor the trends in inequality are alarming (Ahluwalia 2011;

Anjana Thampi

anjana.thampi@yahoo.com

1 Jindal Global Law School, O. P. Jindal Global University, Sonepat, Haryana, India 
Bhagwati and Panagariya 2013; Bhalla 2017). The Gini coefficient of monthly per capita consumer expenditure increased from 0.326 in 1993-1994 to 0.375 in 2011-2012. ${ }^{1}$ The argument that a Gini coefficient of 0.375 , or that its rise by 4.9 percentage points between 1993-1994 and 2011-2012, is not high enough to be alarmed is misleading for several reasons.

First, the distribution of consumption expenditure is usually more equitable than the distribution of income and wealth. Second, India is not a low-inequality country when compared to the rest of the world, even in the distribution of consumption expenditure. As per the Gini coefficient of consumption expenditure data compiled by the Global Consumption and Income Project, India ranked 83rd out of 161 countries in 2012. ${ }^{2}$ The distribution of household wealth in India is far more unequal, with a Gini coefficient of 0.740 in 2012 (Anand and Thampi 2016). So is the income distribution, with a Gini of 0.543 in 2011-2012 as per the India Human Development Survey. As per the Situation Assessment Survey, the Gini coefficient of per capita income of agricultural households was 0.587 in 2013. Even these high levels of consumption, income and wealth inequality are likely to be underestimates. It is well-acknowledged that household sample surveys tend to underestimate inequality due to under-reporting and under-sampling of the very rich.

The rise in inequality is also defended on the grounds that it is intrinsic to the growth process that has helped alleviate poverty. However, the official poverty lines in India have been criticised for being abysmally low. It has also been argued that the methodologies of poverty estimation are based on shaky conceptual foundations and do not allow verification of the trend, let alone the magnitude of changes in the poverty ratio (Subramanian 2019). Moreover, the most recent data show a rise in the poverty rate between 2011-2012 and 2017-2018 (Bhattacharya and Devulapalli 2019).

Alternatively, inequality can be seen as leading to intrinsic as well as instrumental problems and the rise in inequality is an important concern even in a developing country like India. Economic equality is needed for the creation of a society where people are treated as fundamentally equal, to bridge the gap between identity groups, for greater representation of the historically marginalised, and for providing equality of opportunity to all (Weisskopf 2011). Inequality can lead to economic instability and crisis, and decline in critical public investment in sectors such as education, infrastructure and research (Stiglitz 2012). A recent study shows that the falling wage share in India negatively affected aggregate demand through its effects on the consumption and import propensity (Dasgupta 2020). Even if the concentration of income at the top end does not reduce the average income levels at the bottom, it is possible that a large segment of the population loses out in dimensions of well-being other than income (Deaton 2013). For instance, unequal distribution of incomes could be

\footnotetext{
1 At the time of writing, the last round of the consumer expenditure survey for which the unit-level data are publicly available is 2011-2012. The latest round of the survey was conducted in 2017-2018, but the data have not been released.

2 Data retrieved from the Global Consumption and Income Project (http://gcip.info/).
} 
Table 1 Distribution of the workforce by usual status of employment (\%)

\begin{tabular}{|c|c|c|c|c|c|c|c|c|c|}
\hline \multirow[b]{2}{*}{ Type of worker } & \multicolumn{3}{|l|}{ Rural } & \multicolumn{3}{|l|}{ Urban } & \multicolumn{3}{|c|}{ Rural + urban } \\
\hline & Male & Female & Person & Male & Female & Person & Male & Female & Person \\
\hline Regular wage/ salaried & 14.3 & 11.0 & 13.4 & 47.2 & 54.8 & 48.7 & 24.4 & 21.9 & 23.8 \\
\hline Self-employed & 57.4 & 59.7 & 58.0 & 38.7 & 34.5 & 37.8 & 51.6 & 53.4 & 52.1 \\
\hline Casual & 28.3 & 29.4 & 28.6 & 14.2 & 10.8 & 13.5 & 24.0 & 24.7 & 24.2 \\
\hline
\end{tabular}

Source: Authors' calculations using PLFS 2018-2019 data

one of the explanations for the limited role of economic growth in improving child anthropometry in India over the past two decades (Thampi 2019).

Extreme inequality in India arises not only from the skewed functional distribution, but also from the persistence of social disparities and hierarchies. The durability of caste inequalities - in land ownership (Anand 2016), in wealth (Tagade et al. 2018), through the continued practice of untouchability (Thorat and Joshi 2020) and through caste-based discrimination in the labour markethas been recorded. Gendered inequalities are also stark and are reflected in women's low participation in the labour market and the disproportionate burden of unpaid work (Ghosh 2019), significant pay gaps and evidence of gender discrimination in the labour market (Deshpande et al. 2018). While the traditional forms of disparities persist, the rise in neoliberalism has superimposed an inequality-inducing regime on the existing stratified society. Studies have warned of the dangers of an uneven growth process, reflected in the high and rising levels of wealth inequality during the neoliberal period (Anand and Thampi 2016) and in the unprecedented rise in the income share of the top $1 \%$ of the population (Chancel and Piketty 2019). This has led to worsening class inequalities (Vakulabharanam 2010), and rise in urban inequality has been identified as one of the drivers of rising disparity (Vakulabharanam and Motiram 2019), along with uneven regional growth patterns and the rising rural-urban gap.

A "unique cocktail of lethal divisions and disparities" (Drèze and Sen 2013, 213) characterises inequality in India. Although advances have been made in social life and in access to amenities over the years, wide disparities continue and have worsened the effects of the pandemic. Earlier studies have covered various dimensions of inequality in India (Himanshu 2018; Haque and Reddy (eds.) 2019). This paper contributes to the existing literature by presenting the latest estimates of inequalities across dimensions and analysing them in the context of the pandemic and the stringent lockdowns in India. Nationally representative household sample surveys relating to several aspects of well-being are used. To understand the labour market and household earnings, we use the Periodic Labour Force Survey (PLFS) data for 2018-2019. For other dimensions, we use the Household Social Consumption: Health and Education modules (2017-2018), and the Drinking Water, Sanitation, Hygiene and Housing Condition (2018) surveys conducted by the National Sample Survey Office (NSSO). 
Table 2 Mean monthly earnings (Rs) by employment type

\begin{tabular}{llll}
\hline Worker type & Male & Female & Person \\
\hline Rural & & & \\
Regular & 13,549 & 8726 & 12,534 \\
Self-employed & 9386 & 4121 & 8688 \\
Casual & 6271 & 3785 & 5672 \\
All & 9137 & 4882 & 8367 \\
Urban & & & \\
Regular & 19,400 & 15,630 & 18,529 \\
Self-employed & 18,272 & 7033 & 16,598 \\
Casual & 7653 & 4675 & 7202 \\
All & 17,389 & 12,213 & 16,393 \\
Rural+ urban & & & \\
Regular & 17,040 & 13,041 & 16,149 \\
Self-employed & 11,566 & 4,911 & 10,657 \\
Casual & 6519 & 3882 & 5922 \\
All & 11,813 & 7,382 & 10,994 \\
\hline
\end{tabular}

Source: Authors' calculations using PLFS 2018-2019 data

\section{Labour Market}

\subsection{Employment Type}

Around $60 \%$ of the workforce in rural areas and $38 \%$ in urban areas are selfemployed (Table 1). About one in four workers in India are casual labourers, with the proportion close to $30 \%$ in rural India. They work mainly as agricultural labourers, construction workers or in public works. Casual workers typically do not work in the same occupation or industry throughout the year, and many among them are engaged in short-term circular migration from rural to urban areas. Self-employed and casual wage workers are predominantly informally employed. Regular wage/ salaried workers have a stable source of income, although there is heterogeneity between them in terms of job security and pay structure. Only about $30 \%$ of them had a written job contract in 2018-2019. The proportion of workers without a written job contract or paid leave has increased over time, indicating increasing informalisation of the workforce.

There is a clear hierarchy in the earnings structure by type of worker, gender and area of residence (Table 2). In spite of being the best-paid worker category in India, regular workers have quite low earnings on average. In 2018-2019, the mean monthly wage of a regular worker was Rs 16,149 , and the median wage was Rs 10,000 - far below Rs 18,000, the minimum pay recommendation of the Seventh Central Pay Commission (Government of India 2015). About $42 \%$ of regular workers earned below Rs 10,000 per month (Table 3). This included 63\% of female regular workers, as compared to $37 \%$ of male regular workers. On the other end, only about $4 \%$ of such workers earned more than Rs 50,000 a month. The workers in the other employment categories are heavily concentrated at the lower end of the 


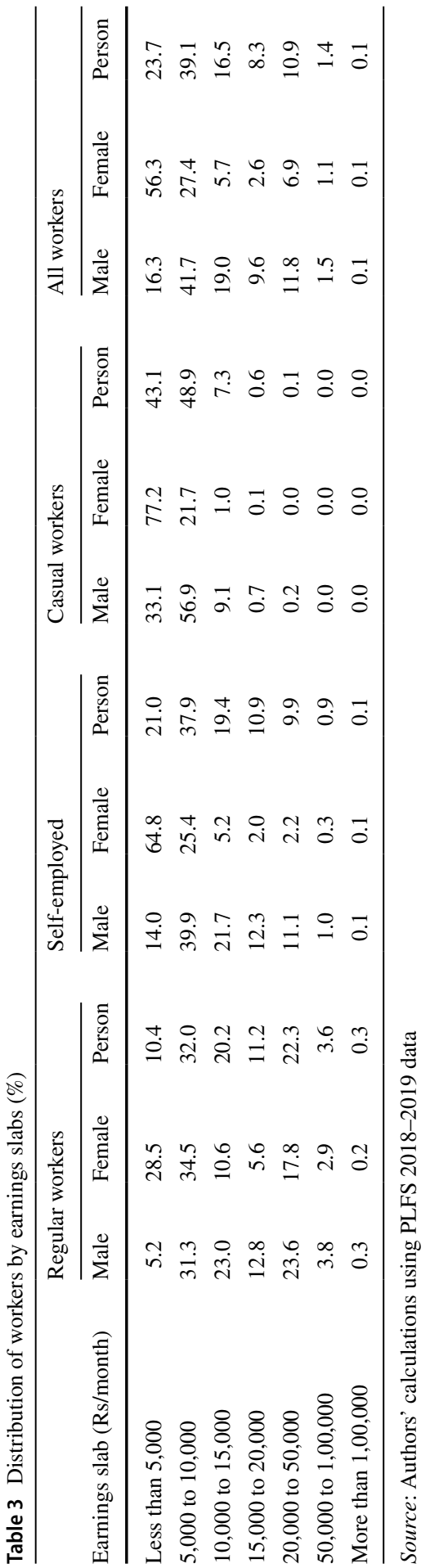




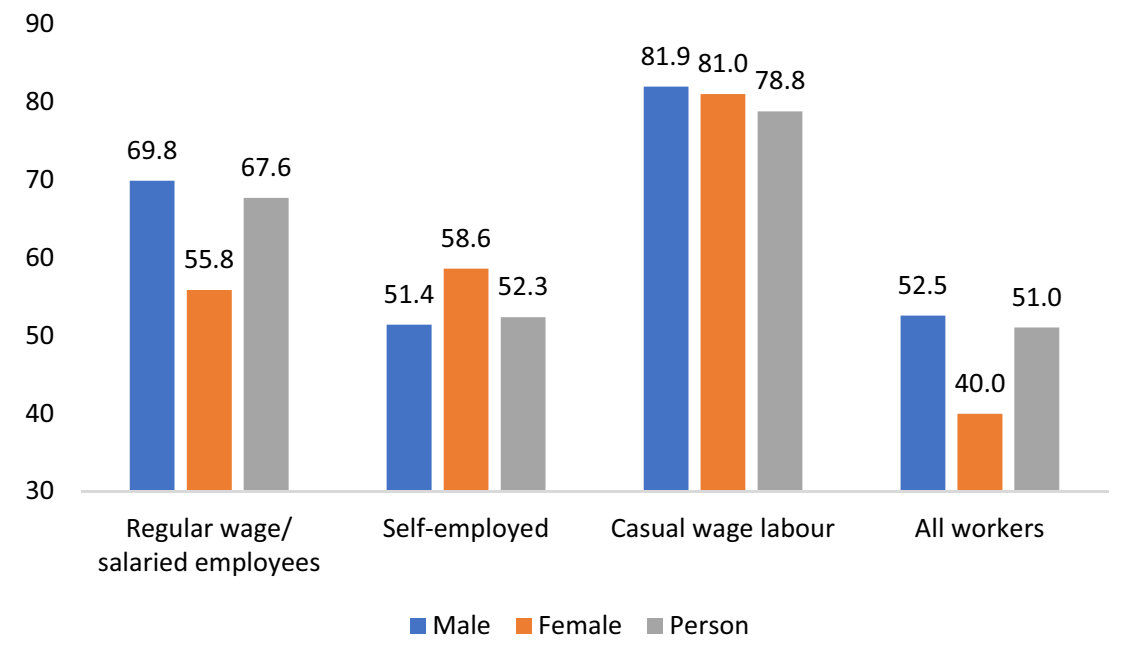

Fig. 1 Rural to urban average earnings (\%) Source: Authors' calculations using PLFS 2018-2019 data

earnings distribution. $92 \%$ of casual workers and close to $60 \%$ of the self-employed earned less than Rs 10,000 per month. This included as much as $90 \%$ of the female self-employed. On the whole, $24 \%$ of Indian workers earned less than Rs 5000 per month and 63\% earned less than Rs 10,000 per month in 2018-2019. ${ }^{3}$ In absolute numbers, of the total workforce of 480 million, 114 million workers earned less than Rs 5000 per month and 301 million workers earned less than Rs 10,000 per month. ${ }^{4}$

\subsection{Area of Residence}

Across worker categories, the average earnings of a rural worker were close to half those of an urban worker. The rural-urban wage gap was the highest for the selfemployed, followed by salaried workers. The sectoral gap was particularly stark for women - a rural female worker earned only $40 \%$ of that of an urban female worker on average (Fig. 1).

\subsection{Gender Gap in Earnings}

It is well-documented that the female labour force participation rate in India has been low and declining over the past few decades. Female workers are only $18-19 \%$ of the paid workforce in rural and urban areas. On average, female workers earned only $43 \%$

\footnotetext{
3 This analysis excludes unpaid family helpers, who are considered as self-employed workers even though earnings are not recorded against their days of work. About $13 \%$ of the total workforce was recorded as unpaid family helper as per the usual status in 2018-2019.

4 We compute these figures using the projected population for January 2019 (1359 million) and the workforce participation rate from the PLFS (35.29\%).
} 


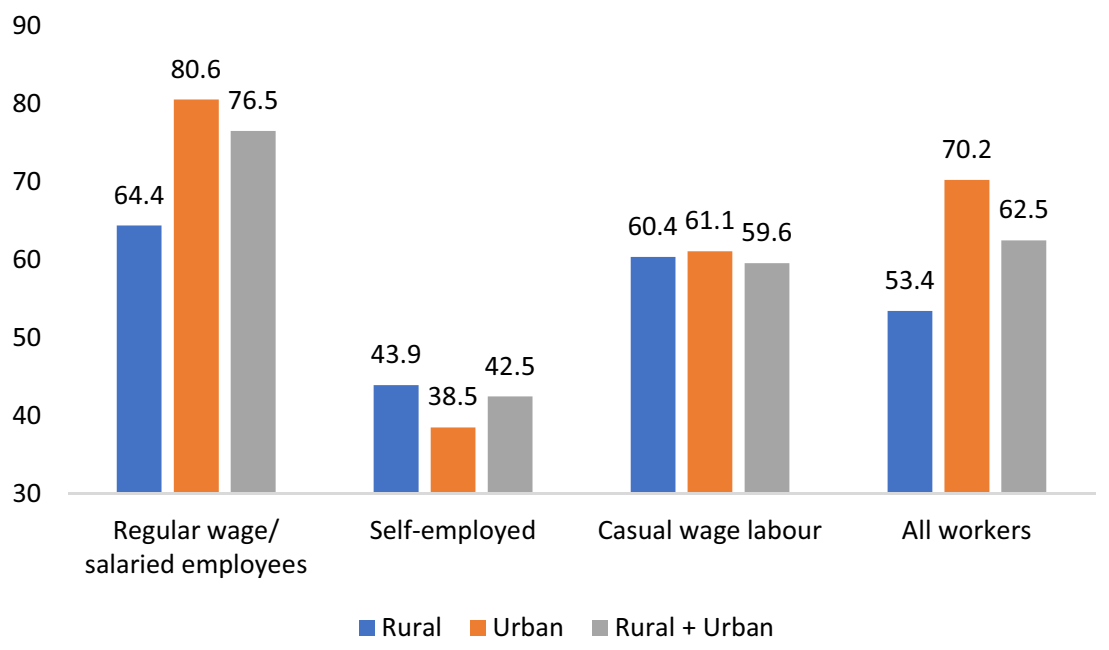

Fig. 2 Female to male average earnings (\%) Source: Authors' calculations using PLFS 2018-2019 data

of male workers when they were self-employed, $60 \%$ as casual workers and $77 \%$ as regular workers (Fig. 2). Considering all employment types, female workers earned $62.5 \%$ of that of a male worker on average. Several studies have shown that a significant proportion of the male-female earnings gap in the labour market is not explained by differences in individual characteristics and can possibly be attributed to discrimination (Duraisamy and Duraisamy 2016; Deshpande et al. 2018).

\subsection{Caste Gap in Earnings}

The Indian labour market is highly segmented along caste lines. The deprived social groups are under-represented in well-paying decent jobs and over-represented in jobs that pay poorly and are hazardous and dehumanising. Studies document job and wage discrimination in the labour market (Madheswaran and Attewell 2007; Madheswaran and Singhari 2017). Deprived social groups, in particular the Scheduled Castes (SCs) and Scheduled Tribes (STs), earn significantly less than the non-ST-SC-OBC group (hereafter Other Castes or OCs) on average, even in regular wage/salaried jobs (Fig. 3). The earning gap is the lowest among casual workers who have very low average wages. On average, a SC worker earns only $55 \%$ of what an OC worker earns, and the earnings gap is higher in urban areas than in rural. The highest earnings gap was among the urban self-employed, with SC workers earning less than half of OC workers.

\subsection{Falling Real Wages}

We next considered the trends in the real wages of regular and casual workers. The year-on-year growth rate of wages of rural workers engaged in agricultural and nonagricultural activities increased significantly between 2007 and 2012 but declined 


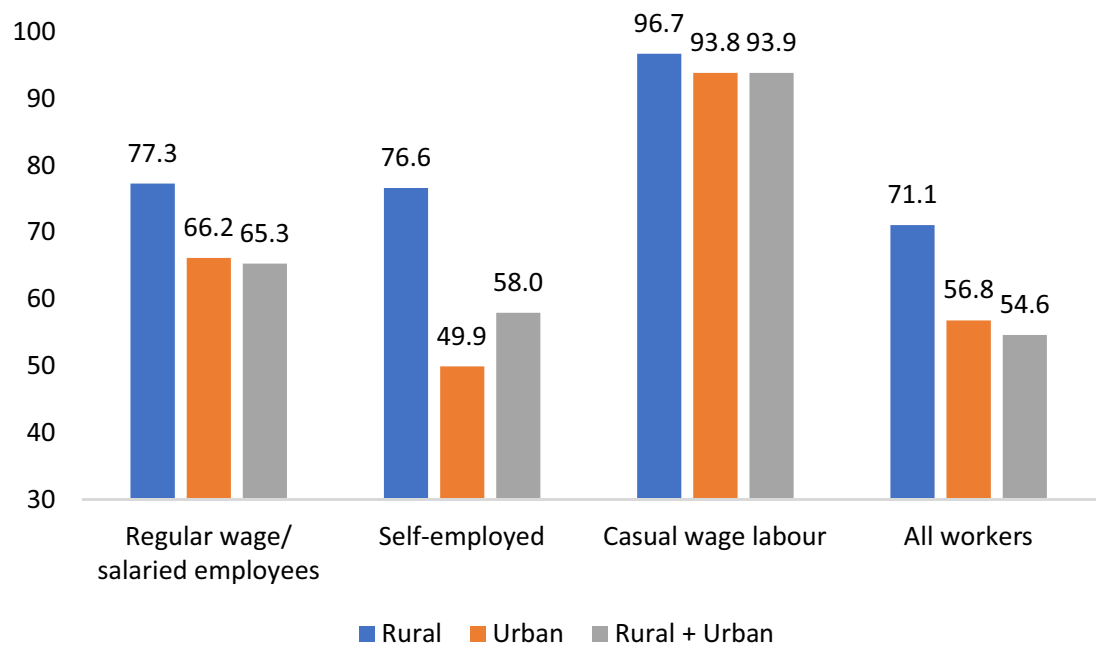

Fig. 3 SC to OC average earnings (\%) Source: Authors' calculations using PLFS 2018-2019 data

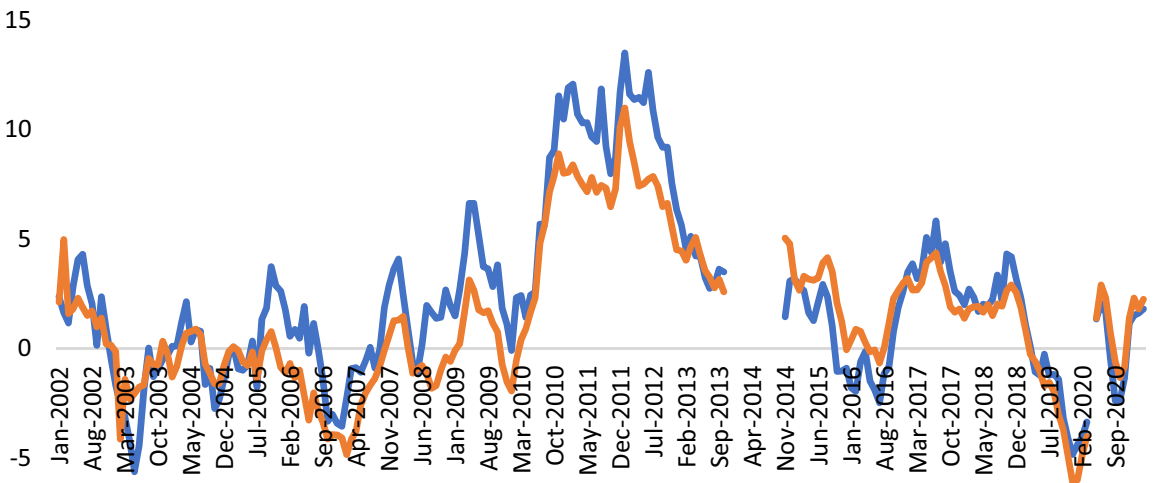

$-10$

$\longrightarrow$ Real Agricultural Wages $\quad$ Real Non-Agricultural Wages

Fig. 4 Year-on-year rural wage growth (\%) Source: Labour Bureau Wage Rates in Rural India series. Note: Nominal wages are adjusted for inflation using CPI (AL) and CPI (RL). Agricultural wages refers to the simple average of the wages for ploughing, sowing, weeding, transplanting, harvesting, winnowing and threshing for the period January 2001 to October 2013 and the simple average of the wages for ploughing/tilling, sowing (including planting/transplanting/weeding) and harvesting/winnowing/ threshing for the period November 2014 to March 2020. Non-agricultural wages refers to the simple average of the wages of carpenters, masons and blacksmiths. The data for November 2013 to November 2014 have not been used to account for changes in the wage series. For a detailed discussion of the changes, see Kundu (2018) 


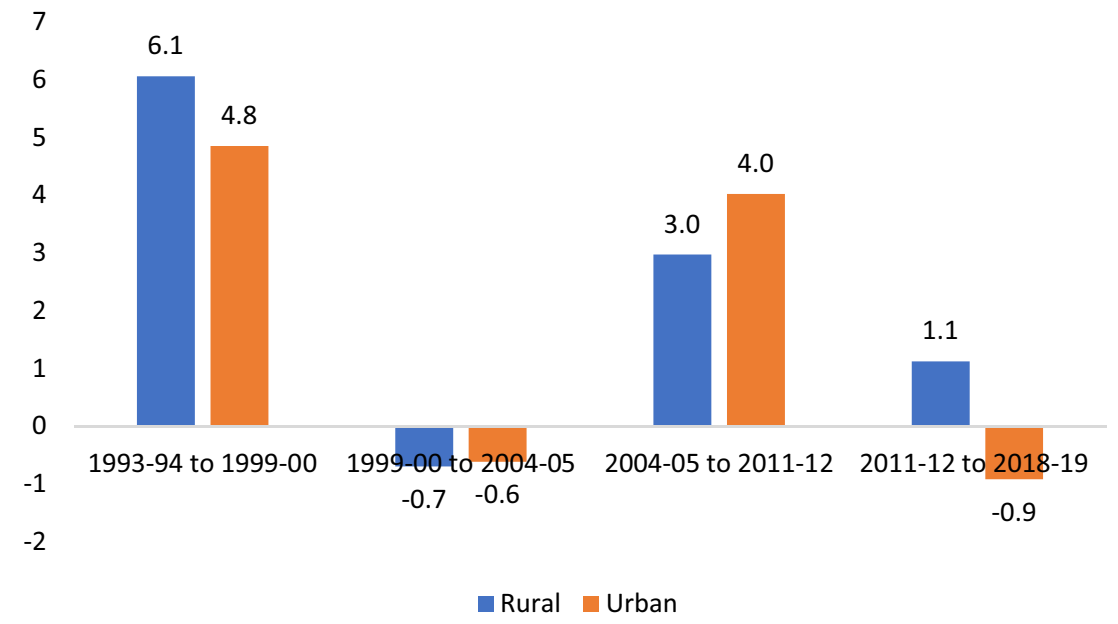

Fig. 5 Growth rate of real wages of regular workers, 15-59 years (\% per annum) Source: Authors' calculations using PLFS 2018-2019 data and National Sample Survey Office (2014). Note: Nominal wages in rural and urban areas were deflated using CPI (AL) and CPI (IW), respectively

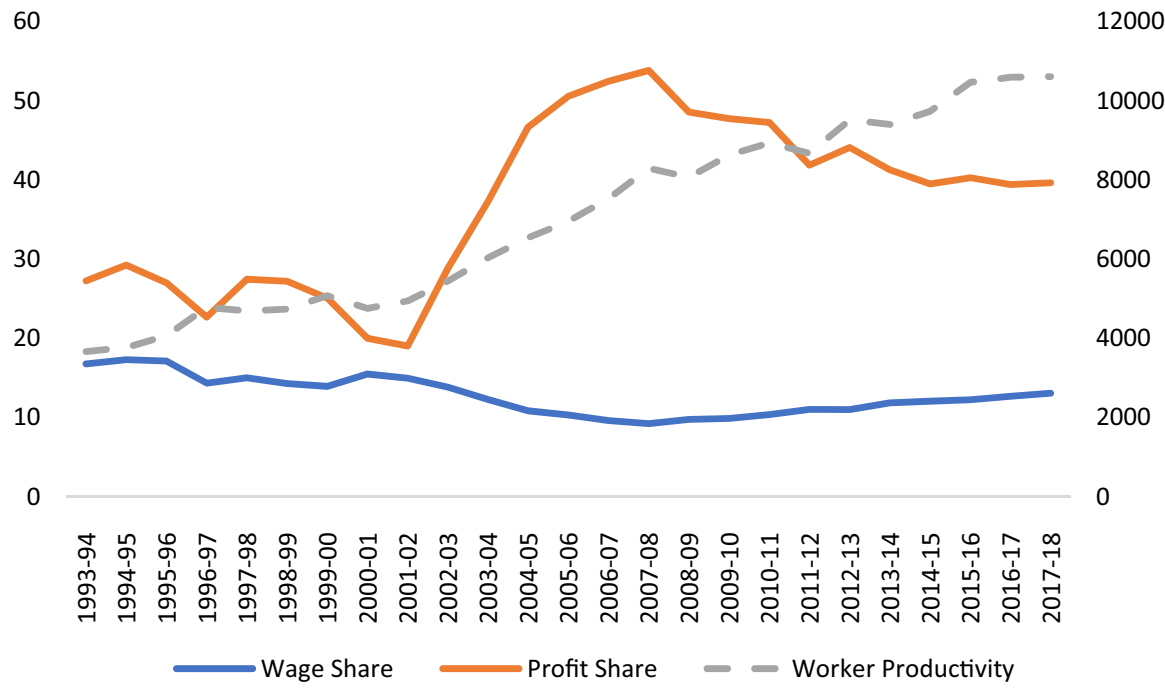

Fig. 6 Wage share, profit share and real productivity in organised manufacturing (\%) Source: Authors' calculations using Annual Survey of Industries data. Note: Wage share refers to the share of nominal wages in nominal gross value added; profit share refers to the share of nominal profits in nominal gross value added; and worker productivity refers to the real gross value added divided by the number of workers. Gross value added is deflated using the consumer price index for manufactured products

sharply thereafter (Fig. 4). Real rural wage growth was negative for the year leading up to the lockdown in 2020 and has remained subdued since then. The reverse migration during the lockdown is likely to have depressed rural wages further, 


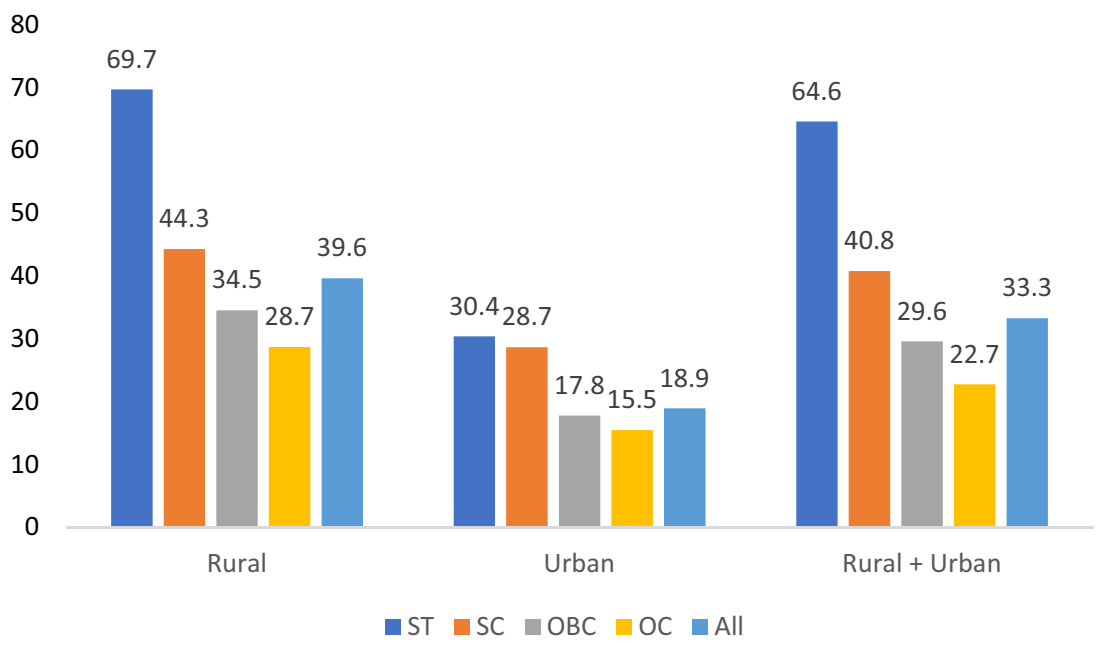

Fig. 7 Population with principal source of drinking water outside premises (\%) Source: Authors' calculations using NSSO Socio-Economic Survey: Drinking Water, Sanitation, Hygiene and Housing Condition 2018 data

particularly in the poorer regions that saw an influx of workers from cities and other states. The real wages of regular workers improved marginally in rural areas and declined by $0.9 \%$ per annum in urban areas between 2011-2012 and 2018-2019, reversing the gains between 2004-2005 and 2011-2012 (Fig. 5). In the organised manufacturing sector, the share of wages in gross value added declined from around $17 \%$ in $1993-1994$ to $13 \%$ in $2017-2018$, and the manifold increase in worker productivity was absorbed largely by the rising profit share (Fig. 6). ${ }^{5}$

\section{Access to Basic Amenities}

\subsection{Water}

About $67 \%$ of the total population, or 905 million people, did not have access to piped water in $2018 .{ }^{6}$ Only about $22 \%$ of the rural population and $59 \%$ of the urban population used piped water as the principal source of drinking water. More than half of the rural population and $14 \%$ of the urban population were dependent on hand pumps, wells, ponds, tankers and springs for their drinking water needs. Even these sources may not be available throughout the year, particularly in summer. For around $12 \%$ of the rural and $10 \%$ of the urban population, drinking water from the

\footnotetext{
5 The wage share increased marginally after reaching its lowest point in 2007-2008 but remained below the 1993-1994 level during the time period under consideration.

6 To estimate the population at the time of the NSSO Socio-Economic Survey: Drinking Water, Sanitation, Hygiene and Housing Condition survey 2018, we use the projected population for October 2018 (1356 million).
} 


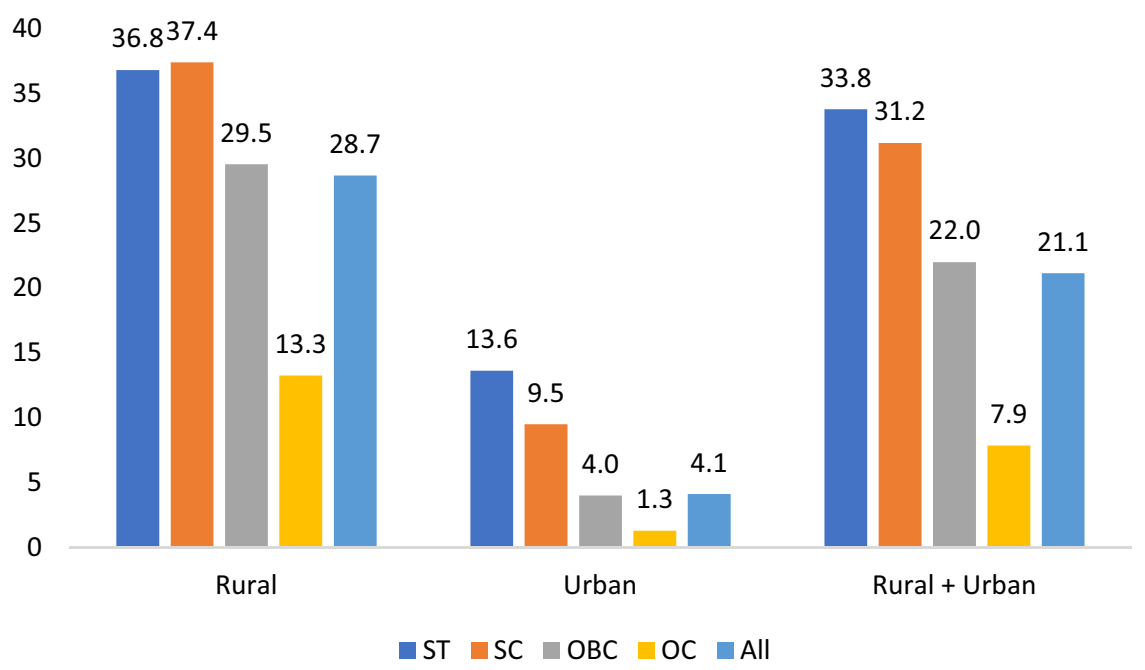

Fig. 8 Population without access to toilets (\%) Source: Authors' calculations using NSSO Socio-Economic Survey: Drinking Water, Sanitation, Hygiene and Housing Condition 2018 data

principal source was not sufficient throughout the year. Overall, this accounted for about 159 million people in India. The water crisis is more severe in certain states, such as Himachal Pradesh, Rajasthan, Madhya Pradesh and Maharashtra, where one-fifth or more of the population did not have access to sufficient drinking water from the main source throughout the year. The crisis also affects STs and SCs more severely than other groups.

For $33 \%$ of the population (40\% of the rural and $19 \%$ of the urban population) about 451 million people-the principal source of drinking water was located outside the premises of their dwelling in 2018. Higher proportions of the ST/SC population faced this problem (Fig. 7). Inequality in the access to water exacerbates gendered inequalities in domestic activities, with women disproportionately bearing the responsibility of fetching water. In about $76 \%$ of the rural households and $50 \%$ of the urban households for which water was not available within the dwelling premises, a female household member had to fetch water.

\subsection{Sanitation}

About $21 \%$ of the total population (29\% of the rural and $4 \%$ of the urban population), or 287 million people, did not have access to any toilet in $2018.70 \%$ had access to a toilet that was only shared with other household members, and $7 \%$ shared the toilet with others in the building. More than half of the rural population in Odisha and more than one-third in Rajasthan, Uttar Pradesh, Bihar, Jharkhand and Tamil Nadu did not have access to any toilet. Lack of access to a toilet was much starker among the ST/SC population, constituting $37 \%$ of them in rural areas and $10 \%$ or more in urban areas (Fig. 8). Regardless of these survey figures from 2018, India was declared open defecation free (ODF) on 2 October 2019. Several reports contradict 


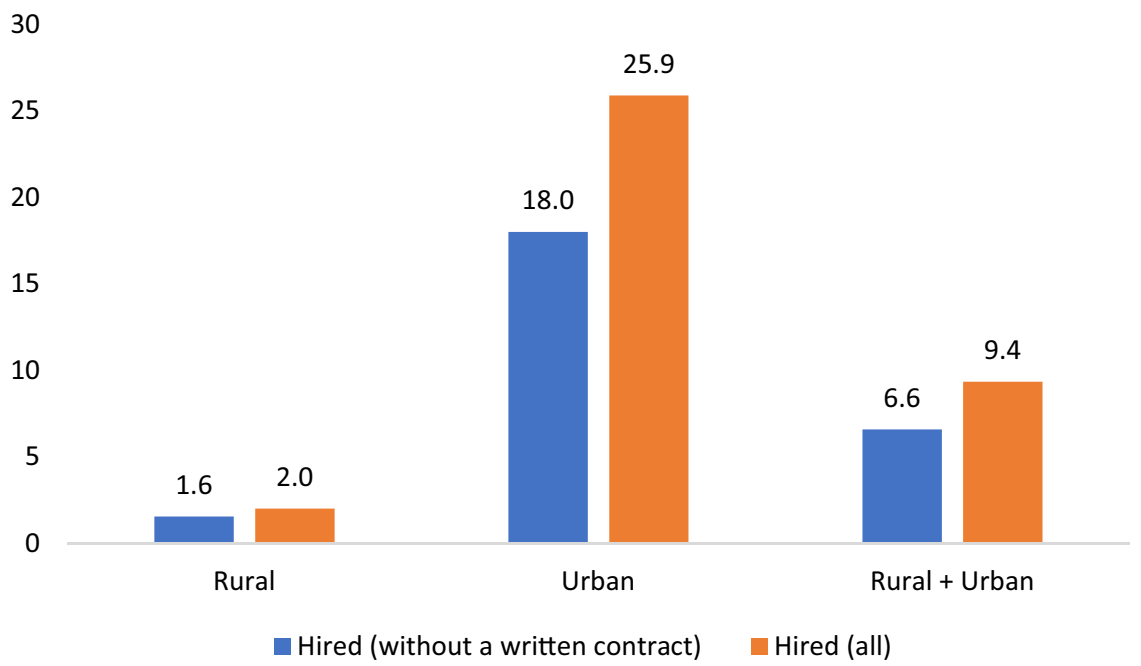

Fig. 9 Population living in rented accommodation (\%) Source: Authors' calculations using NSSO SocioEconomic Survey: Drinking Water, Sanitation, Hygiene and Housing Condition 2018 data

this claim. About half of the sampled households in Rajasthan constructed under the Pradhan Mantri Awaas Yojana did not have a toilet, as per a performance audit by the Comptroller and Auditor General (Sharma 2020).

\subsection{Housing}

\subsubsection{Hired Accommodation and the Burden of Rent}

Around 9\% of the Indian population-126.8 million people-lived in rented accommodations. Rented accommodation is more prevalent in urban areas (Fig. 9). 8\% of the urban population lived in a rented dwelling without any written contract, making it easy for the landlord to evict them at will. The average monthly rent paid by households was Rs 1424 in rural areas and Rs 3306 in urban areas. Rent constituted about $18 \%$ of the household consumption expenditure in rural areas and $23 \%$ in urban areas. This proportion was more than $25 \%$ for urban households in Maharashtra, Andhra Pradesh, Karnataka, Kerala and Tamil Nadu. These findings corroborate media reports that highlighted the predicament of tenants during the lockdown. Several migrant workers in cities were forced to evict their dwellings and return to their villages as they could not afford to pay rent (Joshi 2020).

\subsubsection{Little Room for Physical Distancing}

One-fourth of India's population (339.7 million people) lived in a dwelling with only one room, and 40\% (537 million people) lived in a dwelling with two rooms in 2018 (Fig. 10). 69\% of the households residing in a single room, and $86 \%$ of those residing in two rooms, had more than three members (Table 4). Thus, for a large 


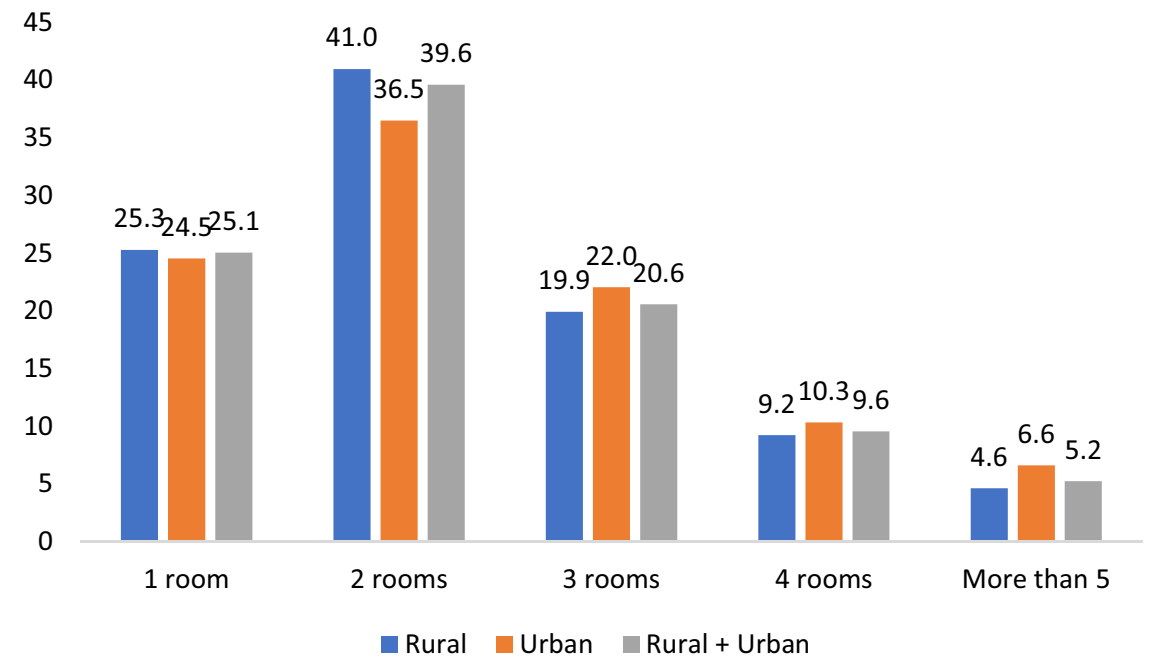

Fig. 10 Population residing in dwellings classified by number of rooms (\%) Source: Authors' calculations using NSSO Socio-Economic Survey: Drinking Water, Sanitation, Hygiene and Housing Condition 2018 data

Table 4 Household size and number of rooms in dwelling $(\%)$

\begin{tabular}{|c|c|c|c|c|c|}
\hline \multirow[t]{2}{*}{ Household size } & \multicolumn{5}{|c|}{ Number of rooms } \\
\hline & 1 & 2 & 3 & 4 & More than 5 \\
\hline 2 or less & 31.5 & 13.7 & 10.1 & 8.3 & 9.1 \\
\hline 3 to 4 & 42.1 & 43.5 & 36.8 & 29.9 & 26.7 \\
\hline 5 to 6 & 21.6 & 32.7 & 34.9 & 33.5 & 29.6 \\
\hline 7 to 10 & 4.7 & 9.6 & 16.5 & 23.5 & 23.9 \\
\hline 11 or more & 0.1 & 0.6 & 1.7 & 4.9 & 10.7 \\
\hline
\end{tabular}

Source: Authors' calculations using NSSO Socio-Economic Survey: Drinking Water, Sanitation, Hygiene and Housing Condition 2018 data

majority of the population, there is little room to follow the Covid-19 guidelines and maintain physical distancing at home if a member gets infected. Around $32 \%$ of the ST/SC population lived in a one-room dwelling, as compared to $20 \%$ of the OC population (Fig. 11). At the other end, about $5 \%$ of the population lived in a dwelling with more than 5 rooms.

\subsubsection{Slums}

The survey collected information on households living in slums or squatter settlements in urban areas. Slums were categorised into notified and non-notified slums, and slum-like settlements with less than 20 households were considered as squatter settlements. About $8 \%$ of the urban population (31.4 million people) resided 


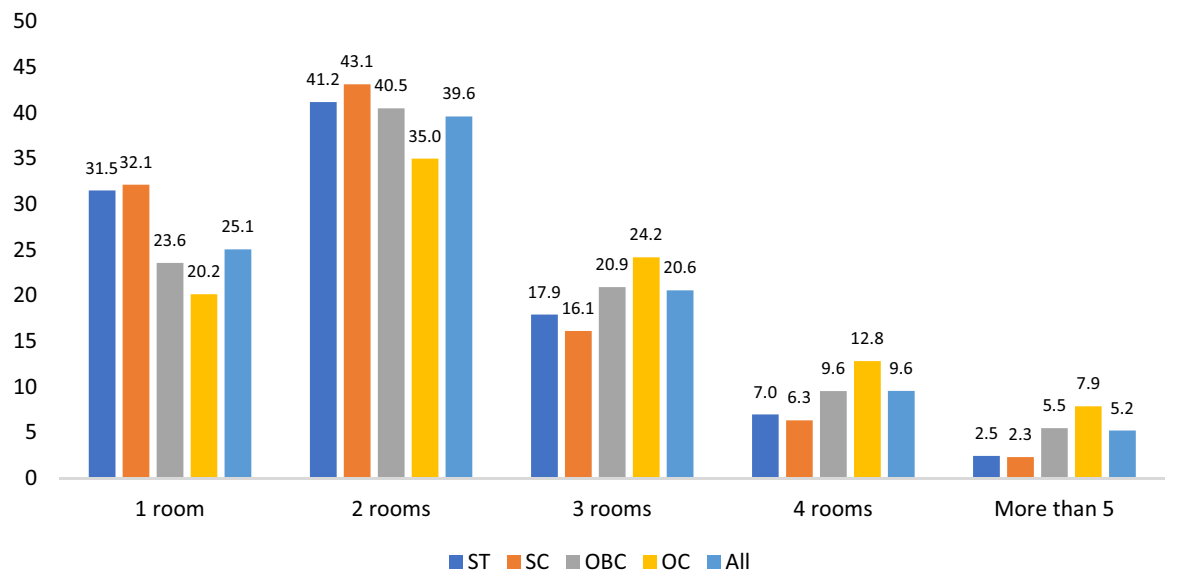

Fig. 11 Population residing in dwellings by number of rooms and by social group (\%) Source: Authors' calculations using NSSO Socio-Economic Survey: Drinking Water, Sanitation, Hygiene and Housing Condition 2018 data

Table 5 Population residing in slums by number of rooms in dwelling $(\%)$

Table 6 Population residing in urban slums by social group (\%)

\begin{tabular}{llllll}
\hline & \multicolumn{5}{l}{ Number of rooms } \\
\cline { 2 - 6 } & 1 & 2 & 3 & 4 & More than 5 \\
\hline $\begin{array}{l}\text { Population (\%) } \\
\text { Household size }\end{array}$ & 51.1 & 34.8 & 10.0 & 2.6 & 1.4 \\
2 or less & 25.4 & 11.7 & 6.8 & 7.3 & 0.0 \\
3 to 4 & 45.0 & 45.2 & 37.1 & 16.1 & 23.2 \\
5 to 6 & 23.3 & 31.6 & 34.6 & 42.7 & 34.7 \\
7 to 10 & 6.0 & 10.9 & 18.3 & 27.2 & 29.1 \\
11 or more & 0.3 & 0.6 & 3.2 & 6.8 & 13.0 \\
Total & 100 & 100 & 100 & 100 & 100 \\
\hline
\end{tabular}

Source: Authors' calculations using NSSO Socio-Economic Survey: Drinking Water, Sanitation, Hygiene and Housing Condition 2018 data

\begin{tabular}{lccccc}
\hline & ST & SC & OBC & OC & All \\
\hline Population (\%) & 13.8 & 14 & 6.0 & 6.3 & 7.6 \\
Documents of head & of slum-dwelling household \\
Ration card & 27.7 & 25.1 & 20.8 & 17.0 & 21.2 \\
Voter ID & 13.6 & 14.7 & 11.0 & 15.3 & 13.5 \\
\hline
\end{tabular}

Source: Authors' calculations using NSSO Socio-Economic Survey: Drinking Water, Sanitation, Hygiene and Housing Condition 2018 data 


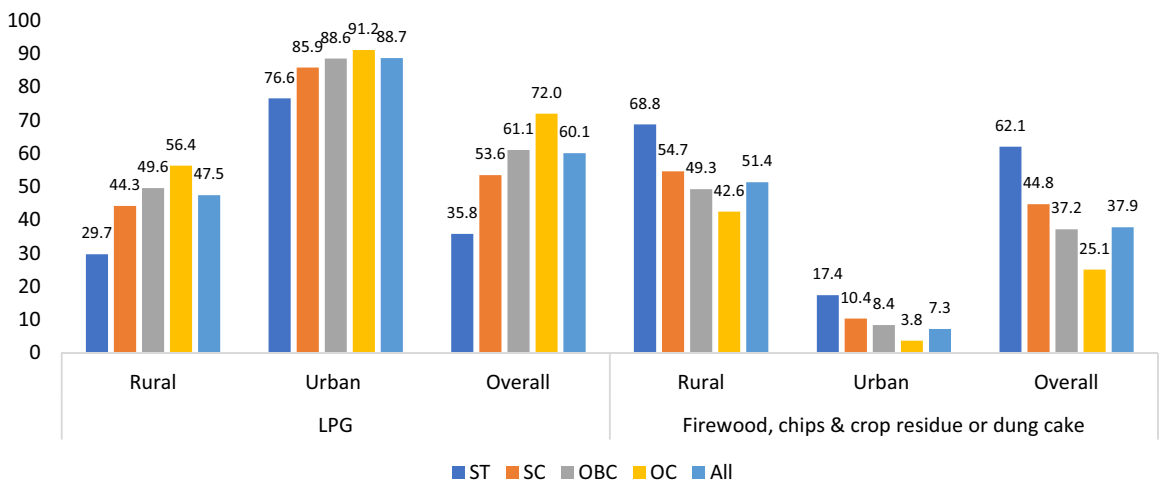

Fig. 12 Population using LPG and firewood for cooking (\%) Source: Authors' calculations using NSSO Socio-Economic Survey: Drinking Water, Sanitation, Hygiene and Housing Condition 2018 data

in slums or squatter settlements in 2018. About half of these people lived in oneroom dwellings, and $75 \%$ of such households had more than 3 members (Table 5). Around $35 \%$ of the people residing in slums had two-room dwellings, and $43 \%$ of such households had more than 4 members. Urban slums were concentrated in a few states, with the proportions as high as 29\% in Andhra Pradesh, 18\% in Maharashtra, Odisha and Chhattisgarh, and $12 \%$ in Delhi.

The proportion of ST/SC urban population living in slums (14\%) was more than double that of OCs (6\%) (Table 6). The heads of only about $13.5 \%$ of the households living in slums had a voter ID, and those of only $21 \%$ had a ration card. The heads of $74 \%$ of the ST/SC households residing in slums did not have a ration card. These numbers point to the limited reach of subsidised food provisioning among the slumdwellers, who are among the most deprived in urban areas.

\subsubsection{Cooking Gas}

Less than half of the rural population and only about $60 \%$ of the total population reported using LPG for cooking in 2018 (Fig. 12). Less than 30\% of the rural population in West Bengal, Jharkhand and Odisha and less than $40 \%$ in Rajasthan, Uttar Pradesh and Madhya Pradesh reported using LPG in 2018. 38\% of the population-513 million people - used firewood or dung cake for cooking in 2018. In rural areas, over half of the population depended on firewood, chips, crop residue or dung cake for cooking. Much higher proportions of the ST/SC populations rely on these sources of fuel.

\section{Health}

Even before the pandemic, the public healthcare system in India was largely neglected, with an increasing reliance on a health insurance-based model. Only around 1\% of the GDP is spent on public health expenditure. The doctor/ 


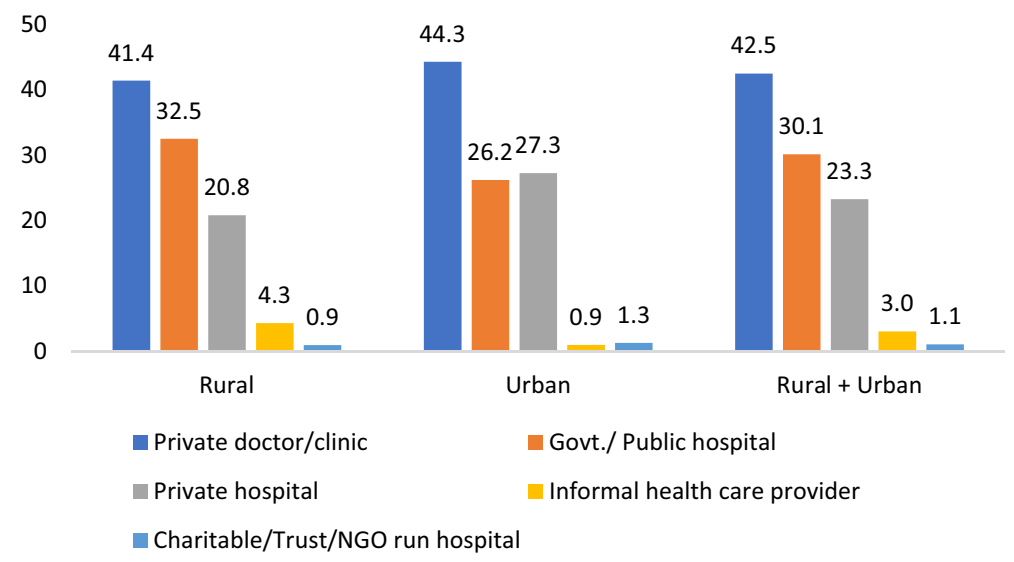

Fig. 13 Treated population by type of facility (\%) Source: Authors' calculations using NSSO Household Social Consumption: Health Survey 2017-2018 data

population ratio was 1:1404 in February 2020 against the WHO prescribed norm of 1:1000 (Ministry of Health and Family Welfare 2020a), and the nurse/population ratio was 1.7:1000 in March 2020 against the WHO norm of 2.5:1000 in March 2020 (Ministry of Health and Family Welfare 2020b).

The healthcare system in India is largely privatised, and $85 \%$ of the population was not covered by any scheme for health expenditure support in 2017-2018. The public sector catered to the needs of less than one-third of the population. Considering hospitalisation and non-hospitalisation cases, only $30 \%$ of the treated population reported going to a public sector hospital or primary health centre/community health centre (Fig. 13). 23\% visited a private hospital, and $43 \%$ visited a private doctor/clinic. $3 \%$ relied on informal healthcare providers. There are stark regional variations in the functioning and use of the public healthcare system. Public sector healthcare providers met the needs of $68 \%$ of the treated population in Himachal Pradesh and 54\% in Tamil Nadu, but less than $20 \%$ of the population in Bihar, Uttar Pradesh, Punjab and Haryana.

When considering only hospitalisation cases, we find that $55 \%$ were treated in private hospitals and $42 \%$ in public hospitals in 2017-2018. The higher reliance on private hospitals was despite the fact that the average medical expenditure per hospitalisation case was about 7 times higher in private hospitals than in public hospitals. Of those who did not use public healthcare for hospitalisation cases, a majority responded either that the required specific service was not available or that the quality was not satisfactory or that a doctor was not available. Disaggregated data show that poor and socially deprived groups depend more on public and informal healthcare providers (Fig. 14). 


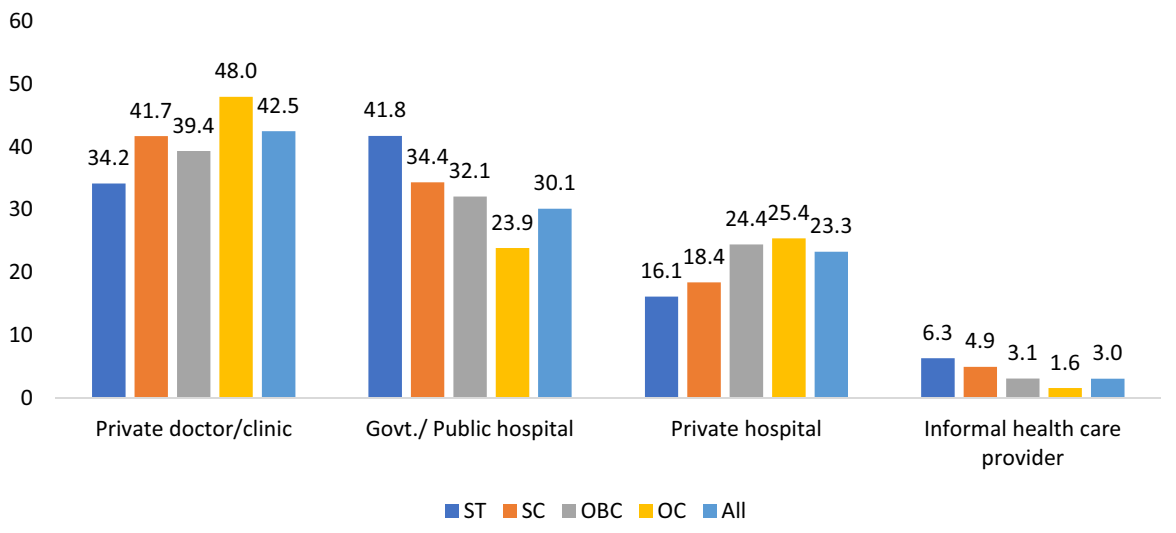

Fig. 14 Treated population by type of facility and by social group (\%) Source: Authors' calculations using NSSO Household Social Consumption: Health Survey 2017-2018 data

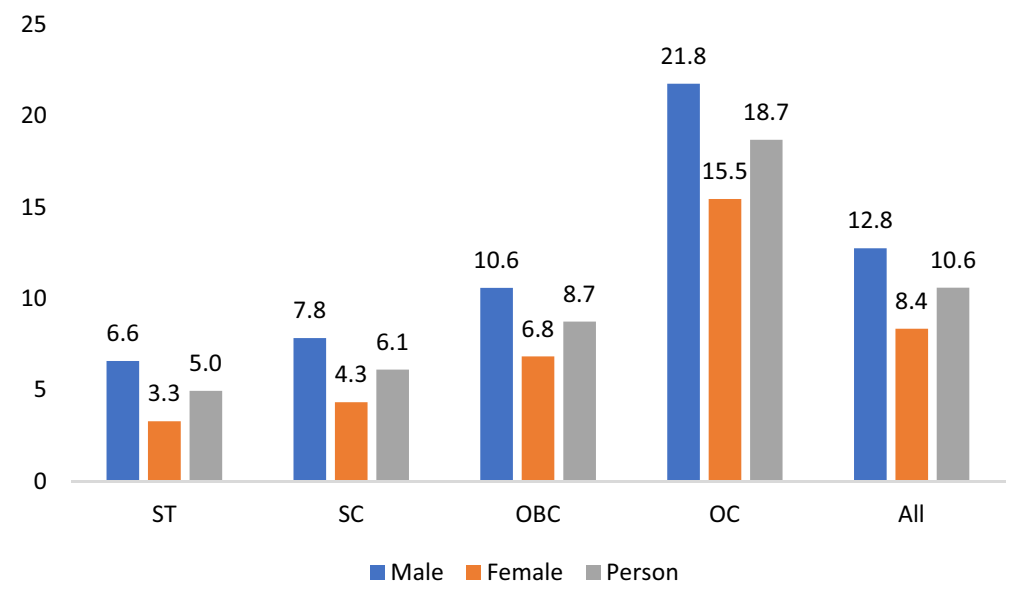

Fig. 15 Population (15 years and above) with a graduate degree or above (\%) Source: Authors' calculations using NSSO Household Social Consumption: Education Survey 2017-2018 data

\section{Education}

Higher education is closely related to mobility and returns in the labour market but continues to remain out of reach for a substantial section of the population. Only around $11 \%$ of the population aged above 15 years held a graduate degree or higher, including in technical courses and diploma/certificate courses in 2017-2018 (Fig. 15). About $44 \%$ of the population aged between 3 and 35 years was attending an educational institution at the time of the survey in 2017-2018 (Table 7). 13.6\% were never enrolled and around $43 \%$ enrolled in the current or previous academic year but were not attending at the time. The proportions of never-enrolled population were significantly higher among STs and SCs, and among females. Even those 
Table 7 Enrolment status of population, 3-35 years (\%)

\begin{tabular}{|c|c|c|c|c|c|}
\hline & ST & $\mathrm{SC}$ & $\mathrm{OBC}$ & $\mathrm{OC}$ & All \\
\hline \multicolumn{6}{|c|}{ Never enrolled } \\
\hline Male & 14.7 & 13.4 & 11.0 & 7.8 & 11.0 \\
\hline Female & 22.4 & 20.0 & 17.6 & 9.4 & 16.6 \\
\hline Person & 18.4 & 16.5 & 14.1 & 8.5 & 13.6 \\
\hline \multicolumn{6}{|c|}{ Ever enrolled but currently not attending } \\
\hline Male & 42.3 & 43.2 & 41.3 & 45.1 & 42.7 \\
\hline Female & 40.4 & 39.0 & 41.2 & 47.5 & 42.2 \\
\hline Person & 41.4 & 41.3 & 41.3 & 46.2 & 42.5 \\
\hline \multicolumn{6}{|c|}{ Currently attending } \\
\hline Male & 43.1 & 43.4 & 47.7 & 47.1 & 46.2 \\
\hline Female & 37.2 & 41.0 & 41.3 & 43.1 & 41.2 \\
\hline Person & 40.3 & 42.3 & 44.7 & 45.3 & 43.9 \\
\hline
\end{tabular}

Source: Authors' calculations using NSSO Household Social Consumption: Education Survey 2017-2018 data

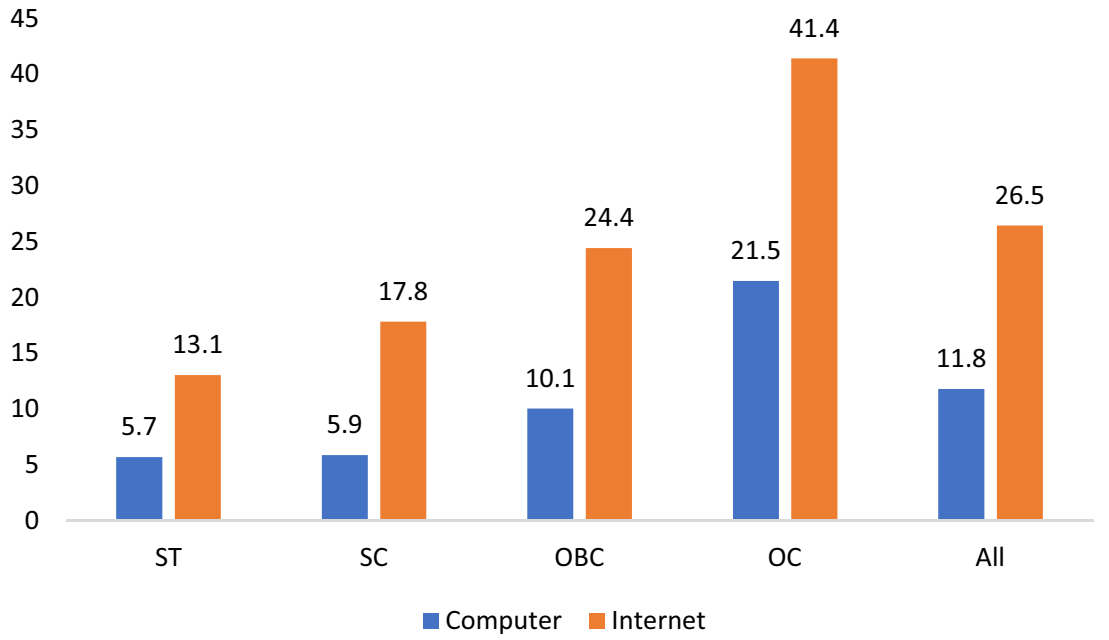

Fig. 16 Proportion of households (with a currently enrolled member) with access to a computer and internet facility (\%) Source: Authors' calculations using NSSO Household Social Consumption: Education Survey 2017-2018 data. Note: Computer includes desktop, laptop, palmtop, notebook, netbook, tablets and other such devices.

enrolled may drop out at various levels of education. The overall dropout rate was around 13\% in 2017-2018, with higher rates for the ST/SC population and females. Financial constraint was reported as the major reason for dropout. Sizeable proportions of the population discontinued their education as they were engaged in economic activities, which can be linked to the economic situation of the household. Around one-third of females dropped out as they were engaged in domestic activities, and $14 \%$ did so due to marriage. 
The pandemic and the subsequent recession have brought on a new crisis in the education sector for disadvantaged social and economic groups. As education moved online during the pandemic, enrolled members of households without access to a computer or a similar device and an internet connection would have been unable to attend classes. Only about $12 \%$ of households (with at least one member enrolled in an educational institution) had access to a computer and only $27 \%$ could access the internet in 2017-2018. ST/SC households were significantly disadvantaged in these respects (Fig. 16). The additional economic distress is likely to have increased dropouts, particularly of the economically and socially deprived groups and female students. A large section of the population faced with loss of employment or incomes may find it difficult to continue the education of their children. Also, lack of access to a computer and internet facilities would exacerbate exclusion with the use of online mode of education. Given the recessionary situation, students who are about to complete their degrees and enter the labour market may also find it more difficult to get employment as per their expectations or qualifications.

\section{Discussion}

The estimates presented in the earlier sections reveal that a sizeable proportion of the Indian population faces substantial inequalities by multiple axes. This created unequal capacities to respond to the Covid-19 pandemic in terms of available savings, continued access to earnings and basic amenities during the lockdowns. Official data were not available at the time of writing, but privately conducted surveys and reports reveal the extent of distress during the lockdowns and the uneven burden of the pandemic (SWAN 2020; Azim Premji University 2021; Right to Food Campaign and Centre for Equity Studies 2021).

The pandemic exposed and deepened the crisis of inequalities that had been building to extreme proportions for a long while. Despite recent bouts of high growth, India's performance in raising the quality of life of the vast majority of its population has been mediocre, as evidenced by poor human development indicators and the persistence of high levels of malnutrition (Drèze and Sen 2013). The pandemic and the recession are likely to worsen such outcomes through various channels, including crises in the labour market and in the access to healthcare and educational facilities.

Various policy suggestions regarding immediate relief from the pandemicinduced distress have been offered, including immediate and adequate cash transfers, universalisation of the public distribution system, strengthening of the rural employment guarantee programme and implementing its urban counterpart (Drèze 2020; Mander et al. 2020). At the same time, medium- and longterm responses need to be based on a more equitable distribution of growth that includes introduction of wealth and inheritance taxes, and universal public provisioning of basic amenities and services such as health, education, housing, sanitation, water and public transport. 


\section{Conclusion: The Need for a Paradigm Change}

The evidence presented in this paper reveals the extent of inequalities in the labour market, the social sector and in the access to basic amenities. A sizeable proportion of the workforce in India continues to be employed in informal work, and about $63 \%$ of the workforce earned less than Rs 10,000 per month in 2018-2019. Substantial disparities by gender, caste and area of residence persist. Access to basic amenities and services such as clean drinking water, sanitation facilities, housing, education and healthcare remains out of reach for millions. The pandemic and the recession have exposed and exacerbated the fragility of India's inequality-inducing regime. The need for a paradigm change-one that puts redistribution at the heart of its agenda-is stronger than ever before.

Acknowledgement We thank the anonymous reviewer for useful comments.

Funding The authors received no funding for this research.

\section{Declaration}

Conflict of interest The authors declare that there is no conflict of interest.

\section{References}

Ahluwalia, Montek S. 2011. Prospects and Policy Challenges in the Twelfth Plan. Economic \& Political Weekly 46 (21): 88-105.

Anand, Ishan. 2016. Dalit Emancipation and the Land Question. Economic \& Political Weekly 51 (47): $12-14$.

Anand, Ishan, and Anjana Thampi. 2016. Recent Trends in Wealth Inequality in India. Economic \& Political Weekly 51 (50): 59-67.

Azim Premji University. 2021. State of Working India 2021: One year of Covid-19. Centre for Sustainable Employment, Azim Premji University.

Bhagwati, Jagdish, and Arvind Panagariya. 2013. Why Growth Matters: How Economic Growth in India Reduced Poverty and the Lessons for Other Developing Countries. New York: PublicAffairs.

Bhalla, Surjit S. 2017. The New Wealth of Nations. New Delhi: Simon \& Schuster.

Bhattacharya, Pramit, and Sriharsha Devulapalli. 2019. "India's Rural Poverty Has Shot Up." LiveMint, 3 December. https://www.livemint.com/news/india/rural-poverty-has-shot-up-nso-data-shows-11575 352445478.html.

Chancel, Lucas, and Thomas Piketty. 2019. Indian Income Inequality, 1922-2015: From British Raj to Billionaire Raj? Review of Income and Wealth 65 (S1): S33-S62.

Dasgupta, Zico. 2020. Income Distribution and Effective Demand in the Indian Economy. CSE Working Paper No. 30. Bengaluru: Azim Premji University. https://cse.azimpremjiuniversity.edu.in/wp-conte nt/uploads/2020/08/Dasgupta_Distribution_Demand_August_2020.pdf.

Deaton, Angus. 2013. The Great Escape: Health, Wealth, and the Origins of Inequality. Princeton: Princeton University Press.

Deshpande, Ashwini, Deepti Goel, and Shantanu Khanna. 2018. Bad Karma or Discrimination? MaleFemale Wage Gaps among Salaried Workers in India. World Development 102: 331-344.

Drèze, Jean. 2020. "DUET: A Proposal for an Urban Work Programme.” Ideas for India, 9 September. https://www.ideasforindia.in/topics/poverty-inequality/duet-a-proposal-for-an-urban-work-progr amme.html. 
Drèze, Jean, and Amartya Sen. 2013. An Uncertain Glory: India and Its Contradictions. Princeton: Princeton University Press.

Duraisamy, Malathy, and P. Duraisamy. 2016. Gender Wage Gap across the Wage Distribution in Different Segments of the Indian Labour Market, 1983-2012: Exploring the Glass Ceiling or Sticky Floor Phenomenon. Applied Economics 48 (43): 4098-4111.

Ghosh, Jayati. 2019. Gendered Labor Markets and Capitalist Accumulation. Japanese Political Economy 44 (1-4): 25-41.

Government of India. 2015. "Report of the Seventh Central Pay Commission." https://doe.gov.in/sites/ default/files/7cpc_report_eng.pdf.

Haque, T., and D.N. Reddy, eds. 2019. India Social Development Report 2018: Rising Inequalities in India. New Delhi: Oxford University Press.

Himanshu. 2018. India Inequality Report 2018: Widening Gaps. New Delhi: Oxfam India.

Joshi, Ajay. 2020. "No Relief: Pay Rent or Leave, Landlords Tell Migrant Workers.” The Tribune, 19 May.

Kundu, Sujata. 2018. Rural Wage Dynamics in India: What Role does Inflation Play? Working Paper Series No. 3, Reserve Bank of India. https://www.rbi.org.in/Scripts/PublicationsView.aspx?id= 18117.

Madheswaran, S., and Paul Attewell. 2007. Caste Discrimination in the Indian Urban Labour Market: Evidence from the National Sample Survey. Economic \& Political Weekly 42 (41): 4146-4153.

Madheswaran, S., and Smrutirekha Singhari. 2017. Social exclusion and caste discrimination in public and private sectors in India: A decomposition analysis. Indian Journal of Labour Economics. https://doi.org/10.1007/s41027-017-0053-8.

Mander, Harsh, Jayati Ghosh, and Prabhat Patnaik. 2020. "A Plan to Revive a Broken Economy." The Hindu, 14 May. https://www.thehindu.com/opinion/lead/a-plan-to-revive-a-broken-economy/artic le31577261.ece.

Ministry of Health and Family Welfare. 2020a. "Shortage of MBBS Doctors." Lok Sabha Starred Question No. 90. 7 February. http://164.100.24.220/loksabhaquestions/annex/173/AS90.pdf.

Ministry of Health and Family Welfare. 2020b. "Shortage of Nurses in India." Rajya Sabha Unstarred Question No. 1362. 3 March. https://bit.ly/3bvLfOu.

Right to Food Campaign and Centre for Equity Studies. 2021. "Hunger Watch Report."

Sharma, Harikishan. 2020. "CAG Report on Rajasthan: In ODF State, Toilets Missing in Half of PMAY Houses Surveyed." The Indian Express, 31 August. https://indianexpress.com/article/india/cagreport-on-rajasthan-in-odf-state-toilets-missing-in-half-of-pmay-houses-surveyed-6576714/.

Stiglitz, Joseph E. 2012. The Price of Inequality: How Today's Divided Society Endangers Our Future. New York and London: W. W. Norton \& Company.

Subramanian, S. 2019. Inequality and Poverty: A Short Critical Introduction. Springer Briefs in Economics. Singapore: Springer.

SWAN. 2020. To Leave or Not to Leave? Lockdown, Migrant Workers, and Their Journeys Home. Stranded Workers Action Network (SWAN).

Tagade, Nitin, Ajaya Kumar Naik, and Sukhadeo Thorat. 2018. Wealth Ownership and Inequality in India: A Socio-religious Analysis. Journal of Social Inclusion Studies 4 (2): 196-213.

Thampi, Anjana. 2019. Has the Economy Left the Children Behind? Nutritional Immiserization in India. In Immiserizing Growth: When Growth Fails the Poor, ed. Ravi Kanbur, Richard Sandbrook, and Paul Shaffer, 176-202. Oxford: Oxford University Press.

Thorat, Amit, and Omkar Joshi. 2020. The Continuing Practice of Untouchability in India: Patterns and Mitigating Influences. Economic \& Political Weekly 55 (2): 36-45.

Vakulabharanam, Vamsi. 2010. Does Class Matter? Class Structure and Worsening Inequality in India. Economic \& Political Weekly 45 (29): 67-76.

Vakulabharanam, Vamsi, and Sripad Motiram. 2019. Role of Urban Inequality in the Phenomenon of Rising Wealth Inequality in India, 2002-2012. In India Social Development Report 2018: Rising Inequalities in India, ed. T. Haque and D.N. Reddy. New Delhi: Oxford University Press.

Weisskopf, Thomas E. 2011. Why Worry about Inequality in the Booming Indian Economy? Economic \& Political Weekly 46 (47): 41-51.

Publisher's Note Springer Nature remains neutral with regard to jurisdictional claims in published maps and institutional affiliations. 